by Gappar Kh. Ergaliev', Vyacheslav (Slava) G. Zhemchuzhnikov², Leonid E. Popov ${ }^{3}$, Michael G. Bassett ${ }^{3}$ and Farkhat G. Ergaliev ${ }^{4}$

\title{
The Auxiliary boundary Stratotype Section and Point (ASSP) of the Jiangshanian Stage (Cambrian: Furongian Series) in the Kyrshabakty section, Kazakhstan
}

\author{
${ }^{1}$ K.I.Satpaev Institute of Geological Sciences, Kabanbai Batyra Street, 69-a, 050010 Almaty, Kazakhstan. E-mail: svenax@bk.ru \\ ${ }^{2}$ North Caspian Oil Development LLP, Almaty, Kazakhstan. E-mail: vgzhem@ rambler.ru \\ ${ }^{3}$ Department of Geology, National Museum of Wales, Cathays Park, Cardiff CF10 3NP, Wales, United Kingdom. \\ E-mail: leonid.popov@museumwales.ac.uk \\ ${ }^{4}$ Dala Mining (TMM International), Koshek-Batyra Street, 5, 050010 Almaty Kazakhstan. E-mail: yergaliyev@hotmail.com
}

The Kyrshabakty section in the Malyi Karatau Range, southern Kazakhstan, has been approved as the Auxiliary boundary Stratotype Section and Point (ASSP) for the base of the Jiangshanian Stage of the Furongian Series (Cambrian System). The first appearance datum (FAD) of the agnostoid trilobite Agnostotes orientalis coincides with the horizon marking the base of the Jiangshanian Stage, and the FAD of A. orientalis occurs at $259.0 \mathrm{~m}$ in the measured section, $61.2 \mathrm{~m}$ above the base of Unit 8 in the Zhumabai Formation. The boundary interval in the Kyshabakty section shows a relatively monotonous succession of carbonate deposits. The section contains an abundance of Cambrian fossils including diverse trilobites, brachiopods, molluscs, bradoriids, protoconodonts and paraconodonts.

\section{Introduction}

At present, the International Subcommission on Cambrian Stratigraphy (ISCS) is keen to designate not only GSSPs for stage and series boundaries but also ASSPs (Auxiliary boundary Stratotype Sections and Points) in excellent sections and, preferably, in palaeogeographic regions different from those where the GSSPs have been designated. ASSPs will serve not only as important regional standards but at some future time an ASSP may be needed as a functional global standard if a GSSP is later determined to be unusable.

Among horizons having potential as stage boundaries within the Furongian Series discussed by Babcock et al. (2005) is the FAD of Agnostotes orientalis (Kobayashi, 1935). The species, as revised by Peng and Babcock (2005), has a narrow stratigraphic range and has been documented from the Furongian sections of Canada, Kazakhstan, South China, South Korea, and Siberia. The GSSP at the A. orientalis level was recently voted on by the ISCS and ratified by the International Commission on Stratigraphy (ICS) and the International
Union of Geological Sciences (IUGS). The GSSP for the stage, now known as the Jiangshanian (formerly provisional Stage 9) is located in the Duibian B section, Zhejiang, China (Peng et al., 2012).

The Kyrshabakty section in the Karatau Range, Kazakhstan, was proposed as the ASSP section of the Jiangshanian Stage, and in 2012 the ISCS voted overwhelmingly to approve it as such. The ASSP point coincides with the FAD of Agnostotes orientalis, which is 259 $\mathrm{m}$ above the base of the measured Kyrshabakty section and $61.2 \mathrm{~m}$ above the base of Unit 8 of the Zhumabai Formation (also referred to in some literature as Bestogai Formation, Ergaliev et al., 2009).

The Karatau Range in South Kazakhstan exhibits one of the finest Cambrian Series 3 to Furongian Series sequences in the world. The section records an abundance of various groups of fossils including diverse trilobites (Lisogor, 1977; Ergaliev, 1979; 1980; 1981; Ergaliev and Ergaliev, 2001; 2008; Chugaeva and Apollonov, 1982; Apollonov et al., 1988), brachiopods (see Holmer et al., 2001 and references therein), molluscs (Gubanov and Peel, 2001), bradoriids (Melnikova et al., 1997), protoconodonts and paraconodonts (Abaimova 1983; Dubinina 2000 and references therein).

The Kyrshabakty section was for a long time considered as the reference section for all major stratigraphic subdivisions of the traditional Upper Cambrian and for biostratigraphic subdivisions of the traditional Middle and Upper Cambrian in the former USSR. Nowadays the section represents the standard for the Series 3Furongian Series in Kazakhstan (Ergaliev and Ergaliev, 2008). The section is easily accessible and has been visited by many specialists in Cambrian geology, palaeontology and stratigraphy.

\section{Geographic and geologic settings}

The Karatau Range represents a north-western extension of the Tien Shan Mountains. It is a system of parallel ridges 50 to $200 \mathrm{~km}$ wide trending north-west over a distance of $400 \mathrm{~km}$. Elevation in the Karatau Range averages 1000 m, and rarely extends above 1500 m; the maximum elevation is $2000 \mathrm{~m}$. Ridges normally extend 50 to $250 \mathrm{~m}$ above the floors of adjacent valleys. The Karatau Range is crossed by a system of parallel river valleys extending trending to the 
north-east and crossing the main geologic structures. This creates excellent conditions for geologic studies, as Proterozoic through Phanerozoic strata are well exposed. Major geologic features, including stratigraphic sequences, can be traced over large distances through the region (Zhemchuzhnikov and Ergaliev, 2010).

The section, which is free from significant unconformities, is a natural exposure situated about $28 \mathrm{~km}$ north-east of the town of Zhanatas along in the middle course of the Kyrshabakty River (Figures 1 and 4). Geographic coordinates for the base of the section are: $43^{\circ} 32^{\prime} 02^{\prime \prime} \mathrm{N}$ and $69^{\circ} 51^{\prime} 28^{\prime \prime} \mathrm{E}$, altitude $527 \mathrm{~m}$. Geographic coordinates of the top of the section are: $43^{\circ} 32$ '27.8' $\mathrm{N}$ and $69^{\circ} 57^{\prime} 24.8^{\prime \prime} \mathrm{E}$, altitude $557 \mathrm{~m}$. The section is within a steep monocline dipping $80^{\circ}$ to $90^{\circ}$ north-east, and not interrupted by major faults.

Conodont alteration indices are low and do not exceed CAI-2.

Cambrian carbonate sediments (Figure 2) exposed in the Kyrshabakty section were deposited along the margin of a carbonate platform situated on an isolated aggrading seamount (Aisha-Bibi seamount; Cook et al., 1991; Zhemchuzhnikov and Ergaliev 2010). The platform, which was situated on the passive margin of an early Palaeozoic plate (Kazakstania), prograded seaward slightly. Faunal affinities suggest that it was situated in relative proximity to South China and the Australasian segment of East Gondwana (Holmer et al., 2001; Popov et al., 2009).

The central part of the Aisha-Bibi seamount had a flat top that was covered by sea water, and was partly lagoonal, in which shallow marine carbonates accumulated and sedimentation consisted largely of pelloidal, algal/cyanobacterial and rare oolitic grainy carbonate material (Zhemchuzhnikov, 1989). The flanks were steep carbonate slopes where accumulated gravity flow deposits (Zhemchuzhnikov, 1986).

The Malyi Karatau exhibits a large variety of carbonate lithofacies including those of a basin plain, carbonate slope, platform margin, and platform interior with a transition to intertidal settings. Early Palaeozoic sedimentation mainly of dark carbonates, shales and black cherts characteristic of the deep basin plain or some continent-margin to slope environments (Babcock et al., 2012). Similar deposits are well documented in surrounding areas, particularly in Bolshoi Karatau and north-east of Malyi Karatau towards the Shu-Sarysu Basin (Zhemchuzhnikov and Ergaliev, 2010). Characters of carbonate sedimentation across the region in the mid-Cambrian to Ordovician show no evidence of any significant influence of local tectonics (Allen et al., 2001; Popov et al., 2009). In spite of subsequent tectonic deformation, the ancient relief of the carbonate seamount is mainly preserved and lithofacies zonation can be reconstructed with certainty.

The Kyrshabakty section is more than $600 \mathrm{~m}$ thick. It includes up to $100 \mathrm{~m}$ of basin plain lithofacies, succeeded by $465 \mathrm{~m}$ of carbonate slope deposits with easily recognizable lithofacies of the outer-fan fringe $(50 \mathrm{~m})$, outer-fan lobe $(175 \mathrm{~m})$, mid-fan distributary channels $(105 \mathrm{~m})$ and inner-fan feeder channels $(135 \mathrm{~m})$. There are some slides and thick $(>10 \mathrm{~m})$ debris flow breccia beds with clasts of shallow water carbonates transported down-slope. Deposits of the upper slope and platform margin have in situ Girvanella and Epiphyton bioherms preserved in the uppermost $60 \mathrm{~m}$ of the measured section (Cook et al., 1991).

Cambrian Series 3 and Furongian rocks are exposed continuously in the area along a distance more than $5 \mathrm{~km}$ to either side of the measured section.

\section{Location of ASSP level and stratigraphic completeness}

The ASSP for the base of the Jiangshanian Stage is located at $259.0 \mathrm{~m}$ above the base of the Kyrshabakty section and $61.2 \mathrm{~m}$ above the base of Unit 8 of the Zhumabai (also known as Bestogai, Ergaliev

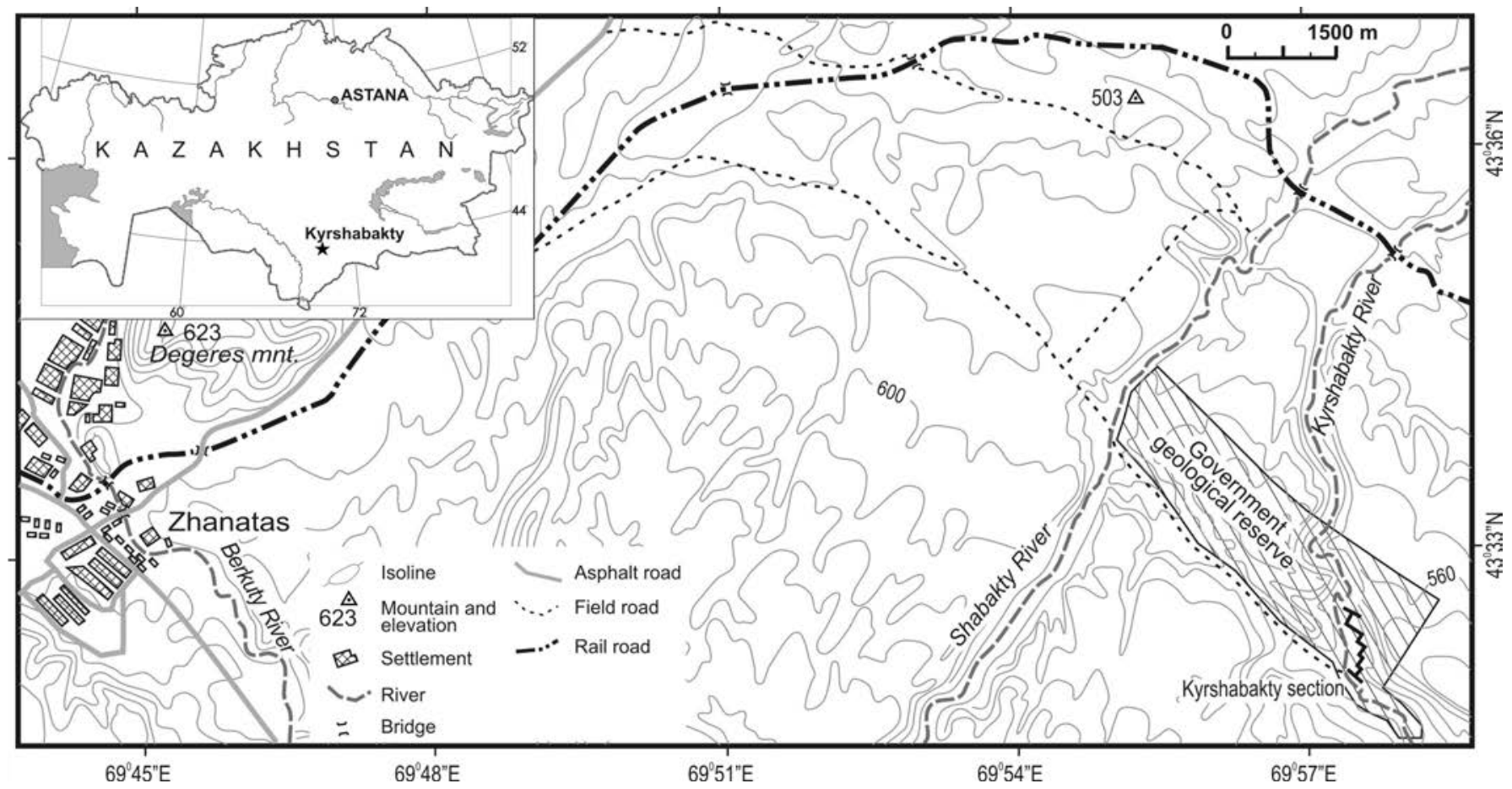

Figure 1.Geographic location of the Kyrshabakty section in relation to major settlements and transport routes.Topographic map of part of the area east of Zhanatas in the Malyi Karatau Range showing boundaries of the Aksai State Geological Natural Reserve and location of the Kyrshabakty section. Inset, Kyrshabakty section within territory of the Republic of Kazakhstan. 


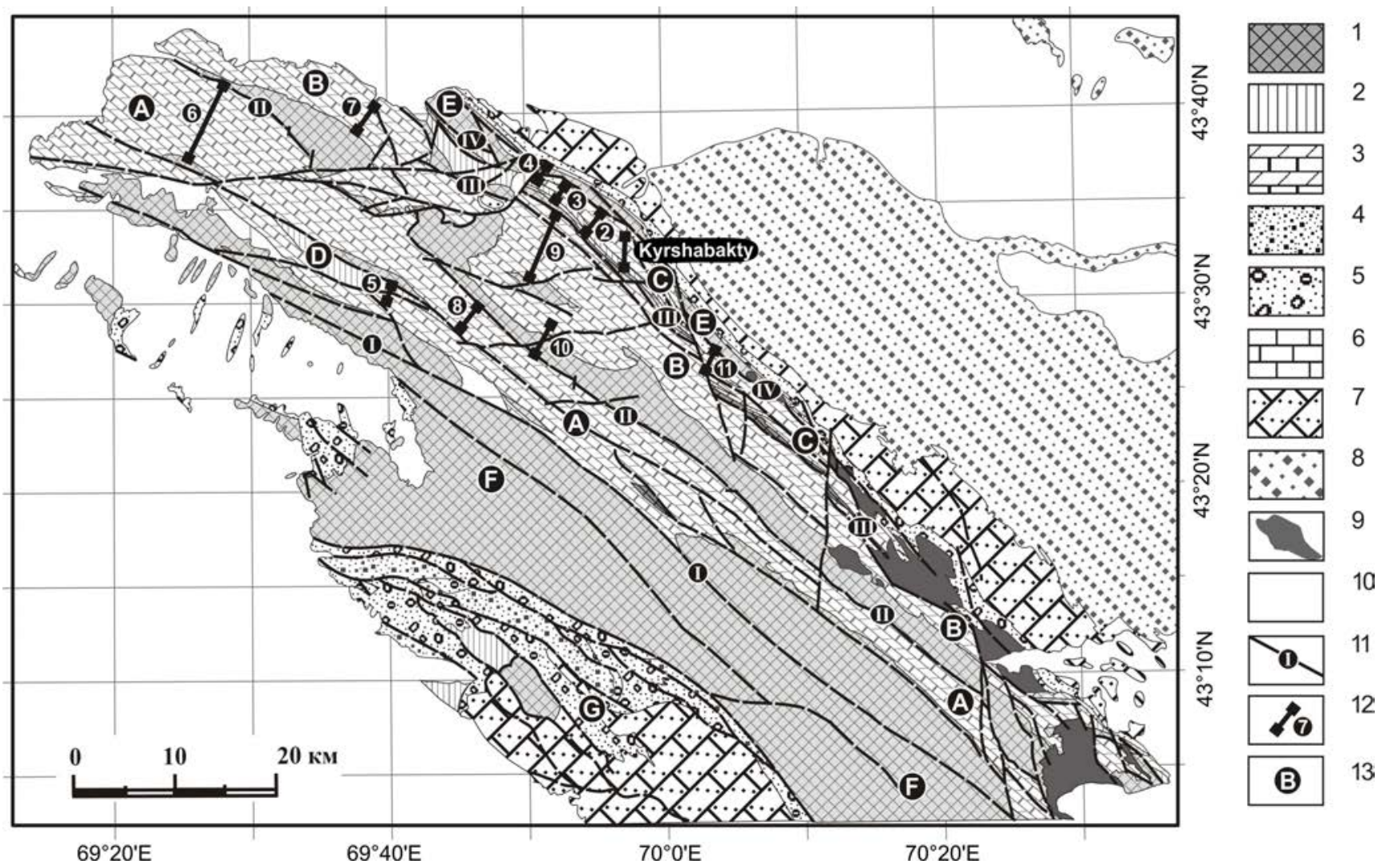

Figure 2. Schematic geologic map of the Malyi Karatau Mountains (modified after Ergaliev and Zhemchuzhnikov, 2011). Legend: 1 - Precambrian undifferentiated shales, limestones and siliciclastics, 2 - Cambrian-Lower Ordovician cherts, shales, limestones and siliciclastics; 3 - Cambrian-Lower Ordovician limestones and dolostones; 4 - Middle Ordovician siliciclastics siltstones, sandstone, units of conglomerates; 5 - Middle Devonian red beds siltstones, sandstones, conglomerate; 6 - Upper Devonian limestoneand dolomites; 7 - Lower Carboniferous limestones; 8 - Lower Permian red beds, siltstones and sandstones; 9 - Middle to Upper Ordovician granites; 10 - Cenozoic undifferentiated sand, clay and boulders; 11 - Faults; 12 - Studied sections with Cambrian and Lower Ordovician successions; 13 Regional geological subdivisions.

Italic numerals in black circles denote large regional faults: I - Bolshekaroi fault, II - Malokaroi fault, III - Aksai fault, IV - Ushbulak fault.

Capital letters in black circles denote tectonic blocks and/or facies areas: A - Bolshekaroi block, B - Malokaroi block, C-Aksai block, D - Zhanatas block, E - Ushbulak block, F - Kokzhot zone, G - Baizhansai area.

Numerals denote sections where studied Cambrian and Ordovician sequences: 1-Kyrshabakty section; 2-Shabakty section, 3 - Batyrbai section, 4 - Batyrbai-bulak section, 5 - Dongulek secton, 6 - Ushbas section, 7 - Koksu section, 8 - Berkuty section, 9 - Ausokkan section, 10 - Aktugai section, 11 - Zhyrukauz section.

et al., 2009) Formation. It is identified by the first appearance of the agnostoid trilobite Agnostotes orientalis (Figure 3).

The boundary interval (Figure 3 ) is a relatively monotonous succession of amalgamated centimetre-scale turbidites showing Ta, Tab and Tbc Bouma divisions with rare metre-scale mass-flow deposits containing carbonate breccia derived from the adjacent carbonate platform. A laterally discontinuous lens of debris flow breccia immediately below the boundary can be used as a local marker for the boundary. Major lithologies are mudstones and wackestones with some oolitic and pelloidal packstones. Sedimentation patterns represented in Series 3 to Furongian Series strata of the Kyrshabakty section indicate a fairly stable carbonate-dominated environment evolving from an outer-fan lobe of the slope to the lower slope of a tropical carbonate platform on an isolated carbonate seamount (Cook et al., 1991).

Deposition occurred well below wave base and was not affected by any significant lithofacies shifts, submarine erosion or non- deposition caused by sea level fluctuations of eustatic or tectonic nature. A few debris flow breccia beds in the boundary interval represent lens-like bodies not more than $2 \mathrm{~m}$ thick, and there is no evidence of significant erosion of underlying sediments at the time of deposition. Detailed biostratigraphic (Ergaliev, 1980, Ergaliev and Ergaliev, 2008; Holmer et al., 2001), lithostratigraphic (Zhemchuzhnikov 1989; Ergaliev and Zhemchuzhnikov, 2011), sedimentologic (Cook et al., 1991) and carbon-isotope chemostratigraphic studies (Saltzman et al., 2000) confirm uninterrupted sedimentation of deep water carbonates through the upper half of the Cambrian.

\section{Stratigraphy}

Biostratigraphic subdivision of the Kyrshabakty section is based on characteristic agnostoid trilobites (Figure 3). Guide species for the Cambrian Series 3 are assigned to the family Ptychagnostidae 


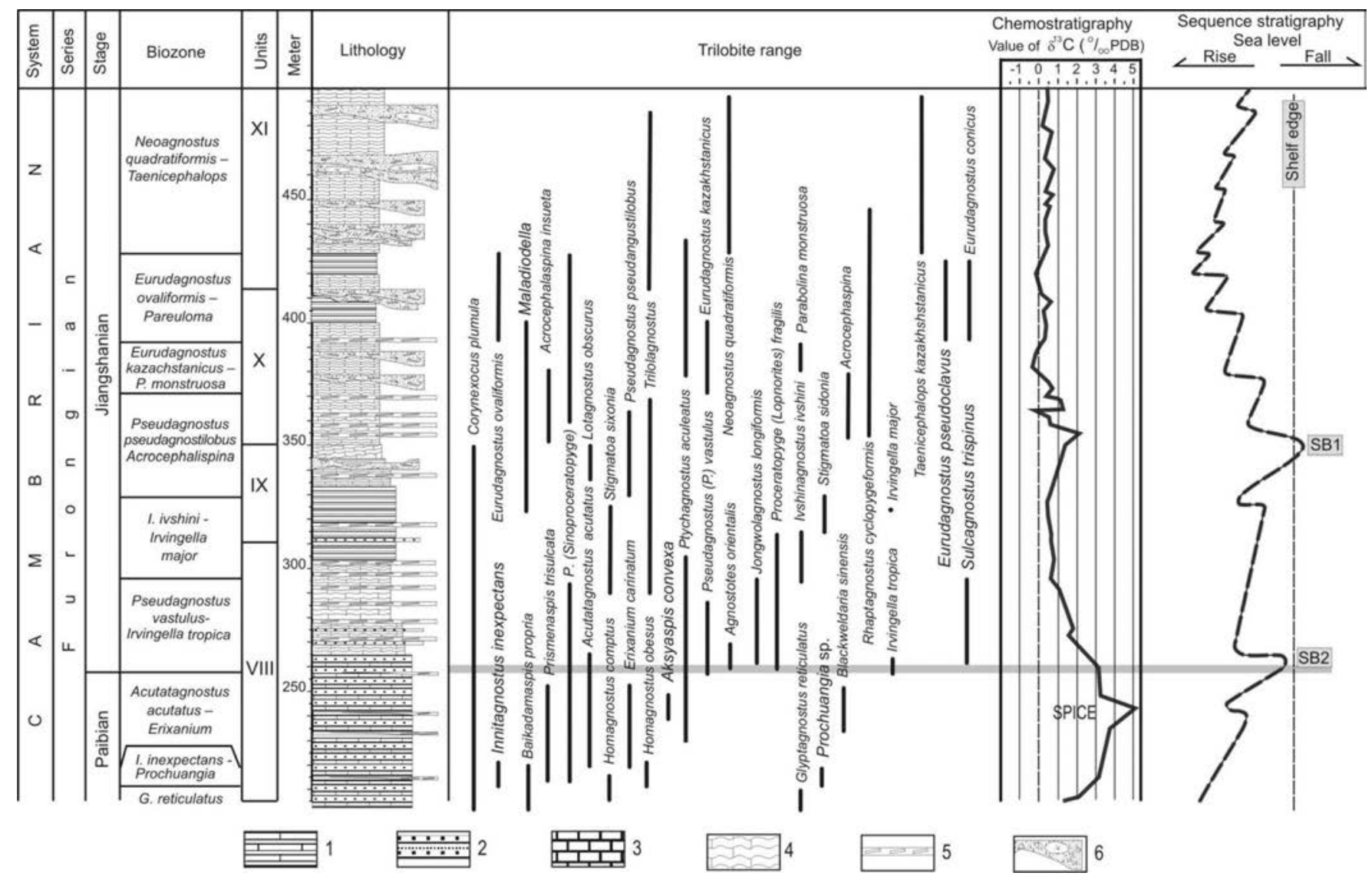

Figure 3. Stratigraphic succession of Cambrian deposits in the Kyrshabakty section, showing revised biostratigraphic units, ranges of selected trilobite taxa (modified from Ergaliev et al., 2008; Ergaliev and Ergaliev, 2008) and sequence stratigraphic interpretation. Plots of $\delta^{13} \mathrm{C}(\%$ PDB) are after Saltzman et al.(2000, Table 1). Lithologic legend: 1 - thin parallel-laminated lime mudstone; 2 - carbonate turbidites of varied grain size; 3 - undifferentiated carbonate wackestone; 4 - bioturbated carbonate (lime wackestone and packstone); 5 imbricated pebble flat carbonate breccia; 6 - debris flow breccia with mixed fragments. SB1 and SB2 - sequence boundaries.

and the subfamily Glyptagnostinae, whereas species of the subfamilies Agnostinae and Ptychagnostinae have been used as guide taxa in the Furongian Series. In the Kyrshabakty section, trilobites are moderately common in Series 3; undergo extinction (which is most obvious among polymerid trilobites) at the beginning of the Paibian Age, and then show increasing diversity as a recovery fauna evolves. Other animal groups, brachiopods in particular, have diversity patterns mimicking that of the trilobites across the Series 3-Furongiuan interval.

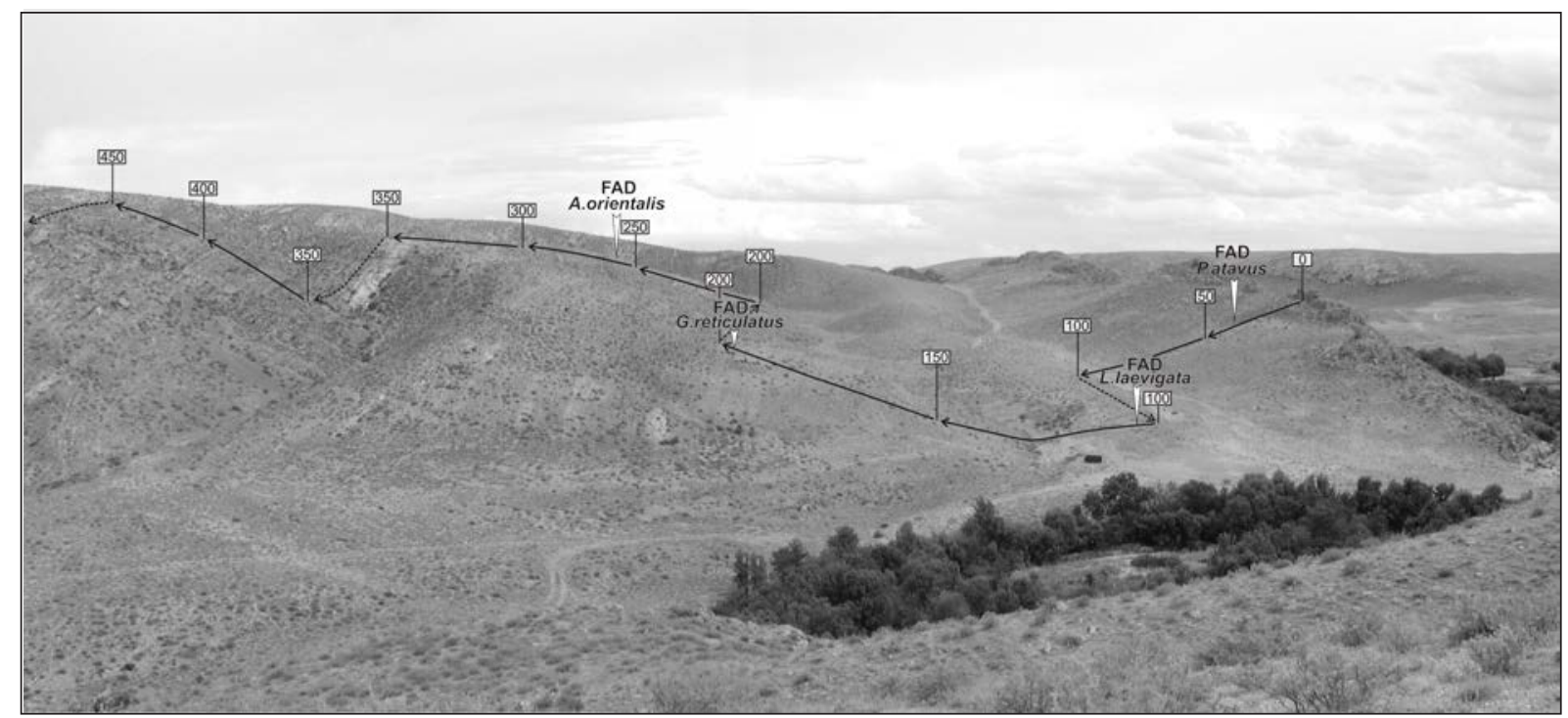

Figure 4. Easterly view of the Kyrshabakty section showing measured intervals in meters, the FAD of trilobite species diagnostic of the Stage boundaries, and position of potential GSSP levels within the section. 

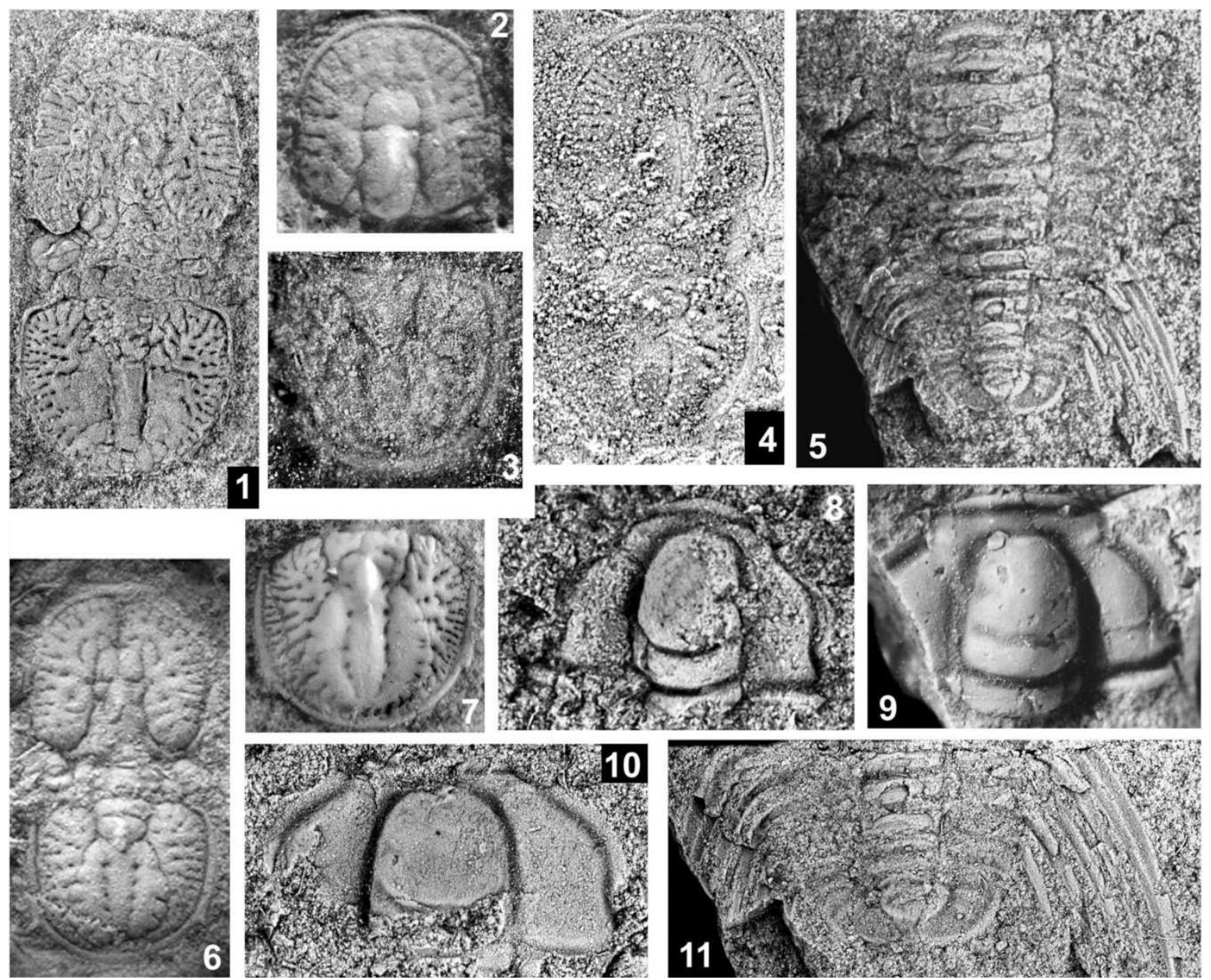

Figure 5. 1-6. Agnostotes orientalis (Kobayashi) from Pseudagnostus (P.) vastulus-Irvingella tropica Assemblage-zone; 1-4, 6, Kyrshabakty section; 5, Batyrbai Section; 14, Acc. IGNA 1950/8051, latex cast of exoskeleton, $\times 3.5$, sample 2004; 2, IGNA 1950/7030, latex cast of exoskeleton, $\times 5.5$, sample 2004; 3, IGNA 1950/3225, cephalon, $\times 12$; sample 1357-3; 4, IGNA 1950/3256, pygidium, $\times 5$, sample 1357-3, 5, 1950/8051, exoskeleton, $\times 7,5$, sample 1466-2; 6, IGNA 1950/3344a, pygidium, $\times 9.5$, sample 1357-2. 7-10, Irvingella tropica Öpik from Pseudagnostus (P.) vastulus-Irvingella tropica Assemblage-zone; 7, IGNA 1950/7060, latex cast of pygidium with attached thorax, $\times 4.3$, sample 2004; 8, 1950/2061, incomplete cranidium, ×6, sample 2004; 9, Acc. IGNA1950/197, cranidium, ×6, sample 1357-1; 10, IGNA 1950/198, cranidium, ×6, sample 1357-1. Specimens are reposited in the K.I.Satpaev Institute of Geological Sciences, Almaty, Kazakhstan (IGNA).

Agnostotes orientalis (Figure 5, 1-6) is an easily recognisable agnostoid taxon with a wide geographic distribution (see Babcock $e t$ al., 2005; Peng and Babcock, 2005). Its first appearance in sections is usually slightly above the first appearance of the polymerid trilobite Irvingella (Babcock et al., 2005, Peng and Babcock, 2005). In the Kyrshabakty section Irvingella tropica Öpik (Figure 5, 7-10) makes its first appearance just $2.0 \mathrm{~m}$ below the ASSP level, where it occurs with another biostratigraphically informative agnostoid, Pseudagnostus (Pseudagnostus) vastulus (Whithouse). In some earlier publications (e.g., Ergaliev, 1980) this species was listed as 'Pseudagnostus curtare'. Most of the other trilobite taxa that occur within the boundary interval are transitional, which confirms relative stability of the environment.

Linguloid brachiopods were strongly affected by the extinction at the beginning of the Paibian Age, and distinctive components of the micromorphic lingulate associations like Linnarssonia, Neotreta, Picnotreta, Rhondellina, Stilpnotreta and some others vanished completely before the Paibian. In the Kyrshabakty section most of the Paibian is poor in brachiopods (Holmer et al., 2001). The first signs of recovery appear in the upper part of the Acutatagnostus acutatusErixanium Assemblage-zone. The appearance of Quadrisonia minor Rowell and Henderson $6.5 \mathrm{~m}$ below the base of the FAD of Agnostotes orientalisis important because it is a relatively widespread taxon that is also known from Laurentia, the Australian sector of Gondwana and the Argentinian Precordillera (Holmer et al., 2001). Aborigenella denudate Koneva, an endemic member of the family Lingulotretidae, is traceable from the early part of the Cambrian to the Tremadocian. It appears $5 \mathrm{~m}$ below the FAD of Agnostotes orientalis. Notiobolus indefinites Holmer et al., 2001 is another endemic form that appears $7.5 \mathrm{~m}$ below FAD of Agnostotes orientalis.

Some regional biostratigraphic subdivisions based on protoconodonts and paraconodonts have been established (An, 1982) they are of limited long-range use because of long stratigraphic ranges of most of the taxa. Only after the appearance of euconodontsis a satisfactory conodont-based biostratigraphic subdivision achieved. In the Malyi Karatau a low diversity protoconodont and paraconodont fauna occurs in the boundary interval. Most of the taxa cannot be used for precise correlation (Abaimova, 1983). 
Cambrian lithostratigraphy developed for Malyi Karatau comprises two sets of the units. One set is applied to shallow water carbonates deposited on the top of the seamount, and the other set is applied to deposits formed on the slopes of the seamount. The slope units tend to be diachronous (Zhemchuzhnikov 1989; Ergaliev and Zhemchuzhnikov, 2011) because the Aisha-Bibi carbonate seamount prograded a little seaward as parasequence sets aggraded upwards (Zhemchuzhnikov, 1989).

The SPICE excursion (Saltzman et al., 2000) in the lower Furongian is one of the most recognisable global oceanographic events of the Cambrian. It is documented from sections in Laurentia, Kazakhstan, South China, Australia, Baltica and Gondwana. The base of the Jiangshanian Stage in Kyrshabakty is $16 \mathrm{~m}$ above the level that corresponds to the point of maximum positive deflection $\left(+4.82 \% \circ \delta^{13} \mathrm{C}\right.$ at $243 \mathrm{~m}$ in the measured section) of the SPICE excursion. Its position correspond to the onset of the negative shift of $\delta^{13} \mathrm{C}(+3.18 \%$ at $260 \mathrm{~m}$, about $1 \mathrm{~m}$ above the ASSP level; Figure 3).

Two major sedimentary cycles, probably second-order sedimentary cycles, are recognised in the Cambrian sequence of Kyrshabakty (Figure 3). They are separated by a Type 1 Sequence Boundary (SB1) about $350 \mathrm{~m}$ above the base of the measured section, in the mid part of the Pseudagnostus pseudagnostilobusAcrocephalina Zone. Several sequences, third-order and lower, separated by Type 2 Sequence Boundaries (SB2) are recognisable within each major sedimentary cycle.

In Kyrshabakty, the base of the Jiangshanian Stage is located within an inferred second-order cycle and at the end of a third-order cycle. Sea level did not fall below the edge of the carbonate platform margin, and the depositional environment through the interval was characterized by relative stability. This is supported by the occurrence of non-eroded, concentrically zoned, redeposited oolitic grains in gravity flow carbonates and by the presence of small imbricate breccias.

\section{Provisions for conservation, protection, and accessibility}

The Kyrshabaty section (Figure 1) is located on public land, and is easily accessible for research without restriction. It is relatively close (less than $30 \mathrm{~km}$ from) the town of Zhanatas, which is the main urban settlement of the region. Zhantas has good transport connections to Taraz and Almaty. The significance of the Kyrshabakty section is recognised by the government of the Republic of Kazakhstan and has been included into the protected area of the Aksai State Natural Reserve since 1985. Any building, landscaping or other activities related to landscape alteration or destruction are strictly prohibited, whereas access to the area for research purposes is unrestricted.

\section{Acknowledgements}

We would like to thank all the geoscientists, especially members of the ISCS, for scientific discussion during their visits to the Kyrshabakty section in Malyi Karatau. We are grateful to Loren E. Babcock, who kindly revised material in the manuscript and made valuable comments. Leonid Popov and Michael Bassett acknowledge logistical and financial support from the National Museum of Wales.

\section{References}

Abaimova, G. P. 1983. Conodonts and other problematic fossils from the Middle and Upper Cambrian of Malyi Karatau, pp.96-104. In Apollonov, M. K., Bandaletov, S. M. and Ivshin, N. K. (eds.). Stratigrafiya i paleontologiya nizhnego paleozoya Kazakhstana [Stratigraphy and palaeontology of the Lower Palaeozoic of Kazakhstan]. Nauka, AlmaAta. Academy of Sciences of the Kazakh SSR, 176 pp. [In Russian].

Allen, M.B., Alsop, G.I. and Zhemchuzhnikov, V.G. 2001. Dome and basin refolding and transpressive invertion along the Karatau Fault System, southern Kazakhstan. Journal of the Geological Society, London, 158, 83-95.

An, T.X. 1982. Study on the Cambrian Conodonts from North and Northeast China: Science Report of the Institute of Geoscience, University of Tsukuba, Section B, no. 3, pp. 113-159.

Apollonov, M. K., Dubinina, S. V. and Zhemchuzhnikov, V. G. 1988. Batyrbai section, South Kazakhstan, U.S.S.R. - potential stratotype of the Cambrian - Ordovician Boundary. Geological Magazine, v.125, pp.445-449.

Babcock, L.E., Peng, S.C., Geyer, G. and Shergold, J.H. 2005: Changing perspectives on Cambrian chronostratigraphy and progress toward subdivision of the Cambrian System. Geosciences Journal, 9, 101-106.

Babcock, L.E., Bevis, M., and MacKenzie, P. 2012. A new class of unconventional hydrocarbon play in the lower Paleozoic of the Appalachian Basin and elsewhere. Classic Rocks. American Association of Petroleum Geologists, Eastern Section, p. 23.

Chugaeva, M. N., and Apollonov, M. K. 1982.The Cambrian-Ordovician boundary in the Batyrbai section, Malyi Karatau Range. Kazakhstan, USSR. In: Bassett, M. G. and Dean, W. T. (eds). The Cambrian Ordovician boundary: sections, fossil destributions, and correlations. National Museum of Wales, Geological Series, no. 3, Cardiff, 77-85.

Cook H. E., Taylor M. E., Zhemchuzhnikov V. G., Apollonov M. K., Ergaliev G. Kh. et al., 1991. Comparison of Two Early Paleozoic Carbonate Submarine Fans. Western United States and Southern Kazakhstan, Soviet Union: Paleozoic Paleogeography of the Western United States -II, Pacific Section SEPM, Vol. 67, 847-872.

Dubinina, S. V. 2000. Conodonts and zonal stratigraphy of the CambrianOrdovician boundary deposits. Trudy Geologicheskogo Instituta RAN, vol. 517, 239 pp. [In Russian].

Ergaliev, G. Kh., 1979. Uninterrupted section Middle and Upper Cambrian and Tremadocian of Malyi Karatau. Transactions of Academy of Sciences of the KazakSSR. No. 4-5, pp.41-52. [In Russian].

Ergaliev, G. Kh., 1980. Middle and Upper Nambrian trilobites from Malyi Karatau. Nauka, Alma-Ata. 208 pp. [In Russian].

Ergaliev, G.Kh., 1981. Upper Cambrian biostratigraphy of the Kyrshabakty section, Malyi Karatau, southern Kazakhstan. In M.E. Taylor (ed.), Short papers for the Second International Symposium on the Cambrian System. Open-File Report 81-743, Colorado, USA, 82-88.

Ergaliev, G.Kh. and Ergaliev, F.G. 2001. Middle Cambrian trilobites and stages of the Malyi Karatau Range (southern Kazakhstan). In Peng, S.C., Babcock, L.E. and Zhu, M.Y. (eds.), Cambrian System of South China. University of Science and Technology Press of China, Hefei, 256.

Ergaliev, G.Kh. and Ergaliev, F.G. 2008. Middle and Upper Cambrian Agnostida of the Aksai National Geological Reserve South Kazakhstan (Kyrshabakty River, Malyi Karatau Range), P.1, Almaty, Gylym, 376.

Ergaliev, G.Kh. Zhemchuzhnikov, V.G., Ergaliev, F.G., Popov, L.E., Ghobadi Pour, M. and Bassett, M.G. 2008. Trilobite biostratigraphy and biodiversity patterns through the Middle-Upper Cambrian transition in the Kyrshabakty section, Malyi Karatau, southern Kazakhstan. In: Gozalo R.R. and Garsia-Bellido D (eds.). Advanced in trilobite research: Fourth International Trilobite Conference, Toledo, June 16-24, 91-98.

Ergaliev, G.Kh., Zhemchuzhnikov, V.G., Popov, L.E., Bassett, M.G., Nikitina O.I., Dubinina S.V., Ergaliev, F.G., Fazylov E.M. 2009. Field excursion guide 14-th International field conference of the Cambrian Stage Subdivision Working Group. Almaty, 70p.

Ergaliev, G.Kh, and Zhemchuzhnikov,V.G. 2011. Stratigraphy of Cambrian and Lower Ordovician deposits of the south of Kazakhstan (Malyi Karatau Mountains). Proceedings of the National Academy of Sciences of the 
Republic of Kazakhstan, Series of Geology and Technical Sciences, No.6 (434), 11-23, [in Russian].

Gubanov, A. P. and Peel, J. S. 2001. Latest Helcionelloid molluscs from the lower Ordovician of Kazakhstan. Palaeontology, 44, 681-694.

Holmer, L. E., Popov, L. E., Koneva S. P. and Bassett, M. G. 2001. Cambrian -Early Ordovician brachiopods from MalyiKaratau, the western Balkhash Region, and northern Tien Shan, Central Asia. Special Papers in Palaeontology, 65, 180 pp. Subcommission on Cambrian Stratigraphy. Annual Report 2003.

Kobayashi, T., 1935. The Cambro-Ordovician formations and faunas of South Chosen, Palaeontology, Part 3, Cambrian faunas of South Chosen with a special study on the Cambrian trilobite genera and families. Journal of the Faculty of Science, ImperialUniversity of Tokyo, Section II, 4, 49344.

Lisogor, K.A. 1977. Biostratigraphy and trilobites of the Upper Cambrian and Tremadocian of MalyiKaratau (southern Kazakhstan). Trudy Sibirskogo Otdeleniya, Instituta Geologii i Geofiziki Akademii Nauk SSSR, 313: 197-265. [In Russian].

Melnikova, L., Siveter, D.J., Williams, M. 1997. Cambrian Bradoriida and Phosphatocopida (Arthropoda) of the former Soviet Union. Journal of Micropalaeontology, 16,179-191.

Peng, S. and Babcock, L. E. 2005. Two Cambrian agnostoid trilobites, Agnostotes orientalis (Kobayashi, 1935) and Lotagnostus americanus (Billings, 1860): Key species for defining global stages of the Cambrian System. Geosciences Journal, 9, 107-115.

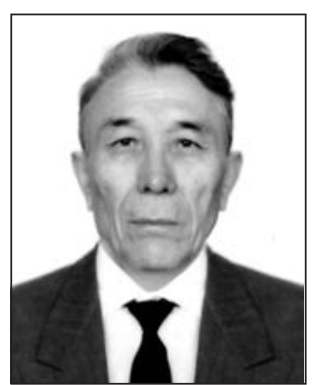

Gappar Ergaliev is a leader of Kazakhstan stratigraphy and head of Regional Geology Department of K.I.Satpaev's Institute Geological Sciences. He is academician of National Academy of Sciences of the Republic of Kazakhstan. He works mainly with trilobite fauna of Kazakh-stan. His main achievement is develop-ment of the stages and zonal subdivi-sions of Upper Cambrian to the terri-tory of former Soviet Union.

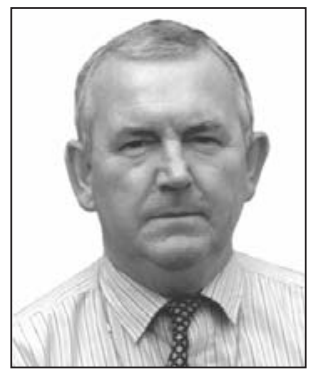

Michael Bassett is the Emeritus Head of the Department of Geology at the National Museum of Wales, Cardiff, United Kingdom and Uppsala University, Sweden. His research interests mostly involve Lower Palaeozoic brachiopods faunas and biostrati-graphy, on a world-wide basis but mainly in the United Kingdom and Scandinavia. He is a past Chairman of the Stratigraphy Commission of the Geological Society of London.
Peng, S. C., Babcock, L. E., and Cooper, R. A. 2012. The Cambrian System. In: Gradstein, F. M., Ogg, J. G., and Ogg, G. (eds.), A Geologic Time Scale 2012. Elsevier, Boston, p. 451-502.

Popov, L.E., Bassett, M.G., Zhemchuzhnikov, V.G, Holmer, L.E. and Klishevich, I.A. 2009. Gondwanan faunal signatures from early Palaeozoic terranes of Kazakhstan and Central Asia: evidence and tectonic implications. Geological Society, London, Special Publications, vol. 325, 23-64.

Saltzman, M.R., Ripperdan, R.L., Brasier, M.D., Lohmann, K.C., Robison, R.A., Chang, W.T., Peng, S., Ergaliev, G.Kh. and Runnegar, B. 2000. A global carbon isotope excursion (SPICE) during the Late Cambrian: relation to trilobite extinctions, organic-matter burial and sea level. Palaeogeography, Palaeoclimatology, Palaeoecology, 162, 211-223.

Zhemchuzhnikov,V.G. 1986. Carbonate breccia in the section of Upper Cambrian and Lower Ordovician deposits in the Batyrbai ravine of the Lesser Karatau area. Lithology and Mineral Resources Magazine, no.6, 76-87, [in Russian].

Zhemchuzhnikov,V.G. 1989. Lithostratigraphy and basin evolution of Late Cambrian and Lower Ordovician Malyi Karatau and North-West Balkhash Area. Ph.D. dissertation in geological and mineralogical sciences. Alma-Ata, 274pp. [in Russian].

Zhemchuzhnikov,V.G., and Ergaliev, G.Kh. 2010. The geology of sedimentary basins of Karatau Range (South Kazakhstan). Proceedings of the National Academy of Sciences of the Republic of Kazakhstan. Geological Series, No. 1(423), 4-23, [in Russian].

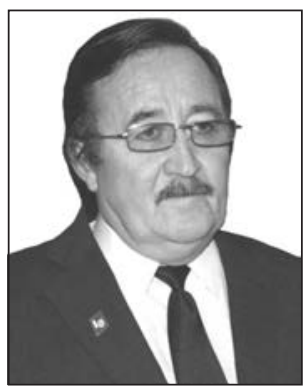

Vyacheslav Zhemchuzhnikov started his carrier as sedimentologist for Paleozoic carbonate sequences of Malyi Karatau mountains and developed model of ancient isolated carbonate seamount, which later called Aisha-Bibi seamount. His recent scientific interest is related to carbonate sedimentary geology of Western Kazakhstan. Presently his interests are on various topics of the Paleozoic petroliferous sedimentary basins of Kazakhstan.

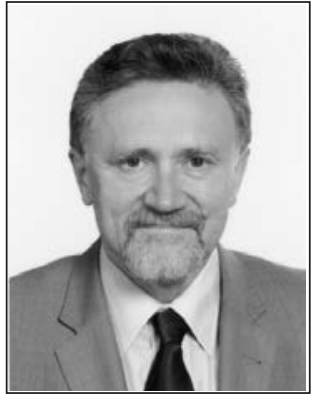

Leonid Popov is a senior research associate at the Geological Depart-ment, National Museum of Wales, Cardiff, United Kingdom with active interests in a number of aspects of global Early Palaeozoic geology and palaeontology, especially Baltoscandia, Central Asia and Iran. He was a titular member of the Subcommission on Ordovician Stratigraphy from 1992 to 2012.

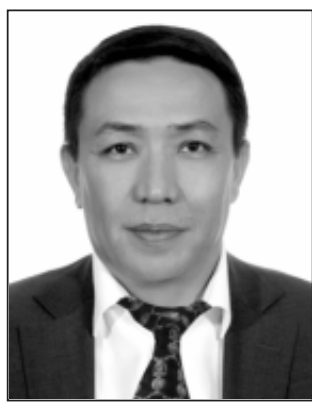

Farkhat Ergaliev, has helped, since young age, his father Gappar in collecting trilobites on Kyrshabakty section. After his graduation from the Geology Department of the University he began to explore mineral resources of Kazakhstan. Currently he has joined a project for ore deposits exploration in Central Kazakhstan. 